\title{
Determining the contributory factors to successful succession and post-succession performance of family-owned SMEs in South Eastern Nigeria
}

\author{
Kenneth Chukwujioke Agbim
}

\begin{tabular}{|c|c|}
\hline \multicolumn{2}{|r|}{ A B S T R A C T } \\
\hline \multicolumn{2}{|c|}{$\begin{array}{l}\text { Objective: This study seeks to determine the contributory factors to successful succession } \\
\text { and post-succession performance. And the role of these factors in the post-succession fi- } \\
\text { nancial and non-financial performance of family-owned SMEs in South Eastern Nigeria. }\end{array}$} \\
\hline \multicolumn{2}{|c|}{$\begin{array}{l}\text { Research Design \& Methods: The adopted quantitative methodology is interview. In } \\
\text { each of the purposively selected } 25 \text { family-owned SMEs, the incumbent, a sibling of the } \\
\text { incumbent and a top level manager were interviewed. In all, } 75 \text { respondents were in- } \\
\text { terviewed. The transcribed interviews were subjected to thematic content analysis. }\end{array}$} \\
\hline \multicolumn{2}{|c|}{$\begin{array}{l}\text { Findings: The contributory factors to successful succession are the characteristics of } \\
\text { succession planning, the incumbent, the potential successor, and the family-owned } \\
\text { SME. The factors that contribute to the post-succession performance are the culture of } \\
\text { making succession planning a continuous process, and the characteristics of the incum- } \\
\text { bent and the family-owned SME. These factors ensure that children of the incumbent } \\
\text { in the SME become more active so as to be selected as potential successors. }\end{array}$} \\
\hline \multicolumn{2}{|c|}{$\begin{array}{l}\text { Contribution \& Value Added: The study identified the contributory factors to success- } \\
\text { ful succession and post-succession performance of the family-owned SMEs. To achieve } \\
\text { successful succession and post-succession performance, the incumbents should incul- } \\
\text { cate the characteristics of these factors into their potential successors. Also, these char- } \\
\text { acteristics should be made part of the culture of the family-owned SMEs. }\end{array}$} \\
\hline Article type: & research paper \\
\hline Keywords: & mily-Owned SMEs; Successful Suc \\
\hline & L25, J12, D19, M13 \\
\hline \multicolumn{2}{|c|}{ Article received: 9 March 2019} \\
\hline
\end{tabular}

\section{Suggested citation:}

Agbim, K.C. (2019). Determining the contributory factors to successful succession and post-succession performance of family-owned SMEs in South Eastern Nigeria. International Entrepreneurship Review (previously published as International Entrepreneurship / Przedsiębiorczość Międzynarodowa), 5(2), 53-73. https://doi.org/10.15678/IER.2019.0502.04 


\section{INTRODUCTION}

Succession is not unique to family firms. Rather, it adds to their importance based on the interactions of the family and business systems. These interactions takes on more complicated direction in family-owned Small and Medium-sized Enterprises (SMEs). This explains why family-owned SMEs can survive, experience improved performance and live long without losing the family character. Iraki (2009) noted that Kongo Gumi based in Osaka, Japan which began in the year 578 AD is the world's oldest family business. The business has employed 39 generations of the Kongo family in the over ten centuries of its existence in the building and repairing of Buddhist temples. Succession involves a series of complex processes whose success or failure can be influenced (Ghee, Ibrahim \& Abdul-Halim, 2015; Molly, Laveren \& Deloof, 2010).

The need for succession planning is critical in SMEs and large enterprises (Krishnan, 2012). A succession process is said to be successful when the successor completely takes over the management and/or ownership of the enterprise (Fan, Wong \& Zhang, 2012). Despite the resistance to and challenges of succession (Bisogno \& Vaia, 2017; Chiang \& $\mathrm{Yu}, 2018$ ), the intergenerational transfer of management and/or ownership can influence the overall performance of a family firm either positively or negatively (Molly et al., 2010). These influences are reflected in the financial and non-financial performance of the firm. Focusing solely on financial measures may imply understating the true overall value generated by the family firm (Astrachan \& Zellweger, 2008). This is because financial measures are a narrow perspective and relying on it alone is inadequate for evaluating the strategic performance of any firm. Moreover, the sole objective of a family business is not financial performance (Salvato \& Moores, 2010).

Family businesses in the Western world are known to have significantly supported the industrialization and economic development of this part of the world. However, this is not so for Africa and Nigeria in particular. As shown in the study by Onuoha (2013a), many of the family businesses fail after the death of the founder. A failed succession can ruin any business, including family business (Fernández-Aráoz, Iqbal \& Ritter, 2015). Irrespective of financial or market power, the succession process has the potential to disrupt and even destroy successful businesses (Bozer, Levin \& Santora, 2017). This is because business transfer is one of the most important and critical events in family business life cycle (Hadryś-Nowak, 2018). In spite of the prevalence of the negative effects of succession from the first to second generation transitions, the quest for improved performance can be facilitated by the organizational learning that takes place within the firm during the first succession (Molly et al., 2010). A family business will benefit greatly if a succession process is run smoothly (Davis, 2014).

Researchers have carried out studies relating management and/or ownership succession to firm performance in different countries, managerial regimes and cultures (Chaimahawong \& Sakulsriprasert, 2012; Cheokas, 2013). Some of the findings are positive (Bocatto, Gispert \& Rialp, 2010), while others are negative (Bennedsen, Fan, JJian \& Yeh, 2015; Kiilu \& Ntale, 2018; Maalu, McCormick, K'Obonyo \& Machuki, 2013). Moreover, despite these studies, the relationship between succession and performance of family businesses in the post-succession period is still unclear. Thus, owing to the varying results and lack of generalized findings, researchers are calling for more studies in this 
area (Giovannoni, Maraghini \& Riccaboni, 2011; Hiebl, 2013; Prencipe, Bar-Yosef \& Dekker, 2014; Salvato \& Moores, 2010; Surdej \& Wach, 2012) especially in developing countries (Maalu et al., 2013) like Nigeria.

The people of South Eastern Nigeria are enterprising and are known to found familyowned SMEs. The CEO of most of these SMEs is their founders, while few of the SMEs are controlled by successors. Notwithstanding the predominance and relative growth of these SMEs, the rate at which they are becoming bankrupt, moribund or closing up owing to conflicts associated with succession is unprecedented. These conflicts take the form of management and/or ownership tussle, misappropriation/misapplication of business fund; name calling, physical and/or diabolical fights, litigations and sometimes assassination. Consequently, only few of these SMEs remain in existence after the death of the founder or beyond the second generation.

Research has shown that a limited number of family firms survive to the next generation (El-Chaarani, 2014); a meagre $30 \%$ of family firms survive from the first generation to the second (Poza, 2013), while the other 70\% either fail or are sold (Stalk \& Foley, 2012). This high rate of failure is common with SMEs (European Commission, 2009; Obadan \& Ohiorenoya, 2013). In Nigeria, the high rate of failure has been linked to lack of succession plan and competencies with respect to the successors (Musa \& Semasinghe, 2014; Obadan \& Ohiorenoya, 2013; Onuoha, 2013a, 2013b), and the obnoxious succession laws and multi-cultural nature of Nigeria (Ogundele, Idris \& Ahmed-Ogundipe, 2012).

Despite the failures, there are still successful family-owned SMEs in Nigeria. These family-owned SMEs have contributed to the creation of employment opportunities, maintenance of competition, stimulation of indigenous entrepreneurship, wealth creation, innovations and creativity, foreign exchange earnings, mobilization of savings, and the Nigerian GDP (Ogbechie \& Anetor, 2015). If the contributory factors to the successful succession and post-succession performance of these family-owned SMEs are not identified and applied in the failed and failing family businesses, it can degenerate to more failures as new family businesses are started. Moreover, as the businesses fail, more families may split, unemployment and poverty rate may rise, and the number of youths taking to social vices stand to increase. It is therefore imperative to conduct this study. The objective of the study is to determine the contributory factors to successful succession and post-succession performance, and the role of the post-succession factors in the post-succession financial and non-financial performance of the family-owned SMEs. The study therefore seeks to answer the following research questions:

RQ1: What are the contributory factors to the successful succession of the familyowned SMEs?

RQ2: What are the factors that contribute to the post-succession financial and nonfinancial performance of the family-owned SMEs?

RQ3: What role does the post-succession factors play in the post-succession financial and non-financial performance of the family-owned SMEs. 


\section{LITERATURE REVIEW}

\section{Family-owned SME}

The European Commission (2008) define a family-owned business as a firm where firstly, the majority of decision-making rights is in the possession of the natural person(s) who established the firm, or in the possession of the natural person(s) who has/have acquired the share capital of the firm, or in the possession of their spouses, parents, child or children's direct heirs; secondly the majority of decision-making rights are indirect or direct; thirdly, at least one representative of the family or kin is formally involved in the governance of the firm; and lastly, a listed company meets the definition of family enterprise if the person who established or acquired the firm (share capital) or their families or descendants possess twenty five per cent of the decision-making rights mandated by their share capital. This definition is adopted because it accommodates all firms including family-owned SMEs. All SMEs in Nigeria share common characteristics. The SMEs: are either sole proprietorships or partnerships; have labour-intensive production processes; and have centralized management and limited access to long-term capital. Owing to the owner-managers' lack of appropriate management skills and inadequate business capital, many of these SMEs fail and are still failing (Okafor, Onifade \& Ogbechi, 2018).

\section{Family-owned SME succession}

Family business succession is the process of transitioning management and ownership of a business to the next generation of family members (Walsh, 2011). Thus, family business succession is more of a process than an event. The owner who transfers the business is referred to as the "predecessor", while the person to whom the business is transferred to is the "successor". The two types of succession in family business are management (or leadership) and ownership. Management succession is the transfer of management position and responsibilities from the current general manager (the predecessor) to the business' new general manager (the successor). Ownership succession is the transfer of ownership of the business from the current owner to a new owner (Warnar, 2012). Management and ownership succession activities can be undertaken simultaneously. However, it is better to implement the management succession plan first and the ownership succession activities subsequently.

\section{Successful family-owned SME}

Successful family business succession is a continuous process whereby leadership and power is transferred from one family member to the next, while maintaining positive family relationships, and enabling the business to expand and prosper financially (Griffeth, Allen \& Barrett, 2006). Successful leadership succession is referred to as the actions, events, and developments that influence both the transfer of managerial control from one family member to another and the continued profitability of the family firm after the process has occurred (Sharma, Chrisman, Pablo \& Chua, 2001).

\section{Succession planning}

Succession planning is the process of management (or leadership) and/or ownership transition from the founder to the incumbent. The founder's influence on the succession process cannot be completely downplayed (Dumbu, 2018). Succession planning is an on-going 
dynamic process that identifies, selects and develops a potential successor for leadership and other positions critical to the mission of the organization at all levels (Bjursell, 2011; Oduwusi, 2018; Phikiso \& Tengeh, 2017). Succession planning is very important in minimizing the risks inherent in transfer and continuity of the family business (Mejbri \& Affes, 2012). It increases the level of satisfaction of the stakeholders as well as the financial performance (Amran \& Ahmad, 2010; Nordqvist, Wennberg \& Hellerstedt, 2013; Pyromalis \& Vozikis, 2009; Sharma, Chrisman \& Chua, 2003). The incumbent initiates and influences the succession process. However, the potential successor can as well initiate the process by exerting pressure on the founder to relinquish the power and control to him or her (Williams, Zorn, Russell Crook \& Combs, 2013; Ye, Parris \& Waddell, 2013). A family business incumbent can be the founder, predecessor or successor (i.e., a child of the founder, any other family member or a non-family member) who is currently the CEO of the family business. However, in this study, we refer to the incumbent as the successor.

The person trained by the successor in the succession process is the potential successor (Boyd, Botero \& Fediuk, 2014; Cabrera-Suárez \& Martín-Santana, 2012; Hania, 2012; Michel \& Kammerlander, 2015; Miller, 2015; Wang, 2010). A potential successor is a family member that has the necessary traits and willingness to potentially take over the family business but has not or did not assume leadership of the business. A successor on the other hand is the family member who assumes managerial control and eventual ownership control of the family business after the founder has stepped down or has left the family business (Sharma, Chrisman \& Chua, 1997). For the succession process to be successful, the work environment in the family business must directly or indirectly support the process (Kansikas \& Kuhmonen, 2008; Sharma \& Irving, 2005).

\section{Post-succession performance}

In family business succession, the incumbent selects and develops a potential successor with the intent of improving the performance and by extension ensure the continuity of the transferred business. After successful succession, the achievement of the post-succession goals of the incumbent is assessed from the post-succession performance. Therefore, post-succession performance is the financial and non-financial outcome of a firm after a successful succession compared to the predetermined goals. Financial measures show the past performance of a family firm, while non-financial measures depict a long term performance of family firms. Thus, the use of financial and non-financial measures gives a complete overall performance of family firms. Monday, Akinola, Olegbenla and Aladeraji (2014) opined that the financial measures include profits, return on assets, and return on investment and sales. The non-financial measures focus on issues pertaining to customer's satisfaction and customer's referral rates, delivery time, waiting time, employee's turnover, family social capital, family/business culture, commitment, survival, embeddedness, reputation and sustainability (Aderonke, 2014; Colli, 2011; Monday et al., 2014).

\section{Previous empirical studies}

Research has shown that succession planning has a positive relationship with family firm performance (Akani, 2015; Bocatto et al., 2010; Rotich, 2014; Sharma \& Sumita, 2013; Wahjono, Wahjoedi, Idrus \& Nirbito, 2014). Moreover, succession is negatively related to performance (Bennedsen et al., 2015; Chiang \& Yu, 2018). Other studies report positive relationship between succession and performance (Chaimahawong \& Sakulsriprasert, 
2012; Kiilu \& Ntale, 2018); Maalu et al. (2013) found that the relationship is not conclusive. There is also no evidence that a family firm's profitability (financial performance) is affected by succession (Molly et al., 2010).

Relating the incumbents' and successors' characteristics to firm performance, Bouguerra, Yezza and Mzoughi (2016) pointed out that social skills and education have significant effect on post-succession performance, while gender does not significantly affect post-succession performance. Bjuggren et al. (2015) noted that female leadership makes much more of a positive difference for performance in family firms. Aldamiz-Echevarría et al. (2017) proposed that birth order influences the succession process more often if the first child is a male than if it is a female; it is not only a predecessor's decision as many women also decide not to join the family business. Nevertheless, once they are in, family women are very much appreciated as family businesses' managers. Amran (2011) stated that matured owners underperform, while young owners are more aggressive in enhancing firm value. Also, owner's gender and age enhance firm performance.

De Alwis (2016) found that the incumbent's interest to let go positively correlates with initial satisfaction with the business succession process and post-succession performance except unrelated manager successor. Amran and Ahmad (2010) established that successors-managed firms have better firm performance than founder-managed firms. Utami (2017) asserted that personality system succession pattern (successor qualification, entrepreneurial orientation, willingness to take over responsibility, personality traits, management and leadership skills) has a positive and significant impact on the effort to sustain success in family business. Saan, Enu-Kwesi and Nyewie (2018) found that higher level of education of founders and communication of the succession decision, comprising the transfer date, and post-succession roles to all key stakeholders affect the succession process and the success of the transfer. When the founder's level of education is relatively high, there is the likelihood of succession planning in the business, but trust seems to be limited with respect to female owners.

Family business literature is also dotted with studies that have related family business characteristics and post-succession performance. Zahrani, Nikmaram and Latifi (2014) proposed that there is a positive and significant relationship between family business characteristics (especially the tendency of trusted people as successors) and succession planning. Maciel, Ramos, Aguilar and Reyna (2015) stated that family cohesion and adaptability, family commitment with the business, the relationship between the owner-manager and the successor, and the planning and training of the successor influence family relationship in a succession process. Overbeke, Bilimoria and Somers (2015) pointed out that the shared vision between fathers and daughters is central to daughter succession. Self-efficacy and gender norms influence shared vision and when fathers and daughters share a vision for the future of the company, daughters are likely to be transformed into successors. Ghee et al. (2015) found that management styles, relationships among family members, values, beliefs and successor's training significantly influence family business performance levels. Paul, Barde, Abbah and Idika (2017) stated that intra-family relationship is a significant determinant of post-succession performance of family-owned businesses. Aderonke (2014) established that the determinants of culture (age, extended family system, inheritance tradition, preference for sons, marriage) have significant impact on the successful succession of family businesses. The study further 
showed that extended family system followed by inheritance law has the highest effect on the successful succession of a family business.

It can be inferred from the literature review that majority of the studies that focused on family-owned SMEs have employed qualitative methodology. The studies that have investigated the influence of either leadership or ownership succession on family business financial (or non-financial) performance are generally few. Specifically, such studies are rare in Nigeria. The need for this study in South Eastern Nigeria is premised on the fact that majority of the businesses in the zone are family-owned SMEs and most of these SMEs rarely survive beyond the second generation. Moreover, there are varying results on the relationship between succession and family firm performance in the literature; while some studies report positive relationship; others show negative relationship, inconclusive and no evidence of any relationship. These findings suggest that more studies are needed in this area particularly the factors influencing successful succession and post-succession performance. Also, the role of the post-succession performance factors in the post-succession financial and non-financial performance of family-owned SMEs.

\section{MATERIAL AND METHODS}

The qualitative methodology adopted in this study is interview technique. The family businesses selected for interview were purposely chosen based on the following pre-determined criteria: (i) the business is a family-owned SME; (ii) one or more of the business owner's family member work in the business; (iii) the business is in its second generation; (iv) the business is not moribund; ( $v$ ) the business is located in the owner's State of origin or residence; and (vi) the family and non-family employees in the SMEs are knowledgeable and well informed about the SMEs, the founder and the incumbent/CEO.

The study data were generated from twenty five family-owned SMEs in the trading, services and manufacturing sectors that were purposively selected from the five States (i.e., Abia, Anambra, Ebonyi, Enugu and Imo) in South Eastern Nigeria. Although the sample is small, it is however termed adequate and acceptable for an exploratory study of this nature (Jamali, 2009). Five SMEs were studied in each State and in each SME three respondents were interviewed, that is, the incumbent, a sibling of the incumbent and a top level manager. In all, seventy five respondents were interviewed. A sample of three family-owned SMEs in Anambra State was purposively selected to pre-test the interview guide. The pre-test interview was carried out to ensure that all the proxies and constructs in the guide were well captured and free from interpretation errors. The pre-test interviews lasted for approximately one hour for each of the three SMEs. The interview guide (see Appendix) was finetuned based on the observations and notes that were made during the pre-test interview.

Before the commencement of each interview, the respondents were informed of the aim of the study, the concepts in the study, nature of the interview questions and duration of the interview. Verbal permission to audio record the interview was also sought and obtained from the respondents. On the average, each interview lasted for thirty minutes. At the end of each interview, the audio recorded interview was transcribed verbatim. To avoid any form of error or misinterpretation, the respondents were allowed to read through the transcriptions to attest that their words were correctly transcribed. Moreover, the researchers read through all the transcriptions whilst listening 
to the audio. This process guaranteed that the data used for analysis were not compromised in any way. Since the unit of analysis is family-owned SME, the interview transcriptions from the respondents were combined on the basis of the twenty five familyowned SMEs and then subjected to thematic content analysis. Codes were manually assigned to patterns in the quotes identified from the responses. These quotes were sorted to develop the study themes. The names used in reporting the findings are not real names. This was done to avoid revealing the identity of the SMEs and/or giving the public any reason to guess the identity of the respondents.

\section{RESULTS AND DISCUSSION}

The findings from the thematic content analysis are organized based on the identified themes and presented in two subsections. The subsections are the contributory factors to successful succession, and the factors that contribute to post-succession performance and their role in the post-succession performance.

\section{Contributory factors to successful succession}

The identified themes in this subsection are characteristics of succession planning, the incumbent, potential successor and the family SME. The responses from the study show that these characteristics constitute the factors that facilitate successful management and/or ownership succession. These factors, their characteristics and the relevant quotes are presented in Table 1.

Table 1. Summary of the contributory factors to successful succession

\begin{tabular}{|c|c|c|}
\hline Factor & Characteristic & Relevant quote \\
\hline \multirow{3}{*}{$\begin{array}{l}\text { Charac- } \\
\text { teristics } \\
\text { of suc- } \\
\text { cession } \\
\text { planning }\end{array}$} & \multirow{3}{*}{$\begin{array}{l}\text { The continuous or on-going na- } \\
\text { ture of the succession planning } \\
\text { process and the stages in the pro- } \\
\text { cess. The stages are apprentice- } \\
\text { ship, delegating authority, assign- } \\
\text { ing business responsibilities, shar- } \\
\text { ing managerial tasks, manage- } \\
\text { ment and/or ownership are } \\
\text { transferred to the selected suc- } \\
\text { cessor by the retiring founder. In } \\
\text { the event of sudden death, the } \\
\text { South Eastern Nigeria succession } \\
\text { law is applied. }\end{array}$} & $\begin{array}{l}\text { When the founder of this firm retired from active involve- } \\
\text { ment in business and was about to move down to the vil- } \\
\text { lage, he transferred both the management and ownership } \\
\text { of the firm to Chika his son. The founder's reasons for his } \\
\text { action were that of all his children, only Chika combined his } \\
\text { university education and apprenticeship programme in the } \\
\text { business. The founder further told members of the firm's } \\
\text { staff that from his observations; only Chika has the requi- } \\
\text { site education, training, experience, competence, capabil- } \\
\text { ity and trust to run the firm (DanPhil Nigeria Limited). }\end{array}$ \\
\hline & & $\begin{array}{l}\text { AkaGod Ventures Nigeria specifically stated that ... alt- } \\
\text { hough there is no written management and/or ownership } \\
\text { succession plan, potential successors who are interested in } \\
\text { the business go through the succession planning process of } \\
\text { apprenticeship, delegation of authority/assignment of re- } \\
\text { sponsibilities, sharing of managerial tasks, and manage- } \\
\text { ment and ownership takeover from the founder who is } \\
\text { leaving the business. The stages in the succession planning } \\
\text { process enhance successful succession. }\end{array}$ \\
\hline & & $\begin{array}{l}\text {... the continuous nature of succession planning has facili- } \\
\text { tated the successful succession of this firm by helping to } \\
\text { control the conflicts and risks associated with such transfer } \\
\text { in the family and the business, and motivating the poten- }\end{array}$ \\
\hline
\end{tabular}




\begin{tabular}{|c|c|c|}
\hline Factor & Characteristic & Relevant quote \\
\hline & & $\begin{array}{l}\text { tial successor to acquire adequate knowledge, skills, com- } \\
\text { petencies and capabilities required to run the business } \\
\text { (IzuGold Global Resources). }\end{array}$ \\
\hline \multirow{4}{*}{$\begin{array}{l}\text { Charac- } \\
\text { teristics } \\
\text { of the in- } \\
\text { cumbent }\end{array}$} & \multirow{4}{*}{$\begin{array}{l}\text { Integrity, capability to teach, ca- } \\
\text { pacity to tolerate or discipline } \\
\text { when necessary, level of training } \\
\text { received, competencies and skills } \\
\text { acquired, capabilities, commit- } \\
\text { ment to the business, willingness } \\
\text { to delegate authority, willingness } \\
\text { to network, willingness to take } \\
\text { risk, willingness to assign respon- } \\
\text { sibilities, capacity to trust others, } \\
\text { willingness to give adequate com- } \\
\text { pensation, educational status, } \\
\text { health condition, age, level of ex- } \\
\text { periences garnered, and gender } \\
\text { blindness. }\end{array}$} & $\begin{array}{l}\text { The founder of this business is an educated man, trained } \\
\text { in business through apprenticeship and has carried on his } \\
\text { own business with so much integrity, commitment and } \\
\text { diverse capabilities. Before retirement he ensured that } \\
\text { these qualities were inculcated into members of his fam- } \\
\text { ily and staff of his business. These qualities helped to } \\
\text { make the succession successful (WhiteGold Nigeria Lim- } \\
\text { ited). }\end{array}$ \\
\hline & & $\begin{array}{l}\text { The qualities possessed by our CEO helped this firm to } \\
\text { achieve successful management and ownership succession } \\
\text { (AguOne Nigeria Limited). }\end{array}$ \\
\hline & & $\begin{array}{l}\text { Some of the reasons the management and ownership } \\
\text { transfer in this business was made possible include the } \\
\text { level of training received by the CEO, his willingness to del- } \\
\text { egate authority, network, take risk, and assign responsibili- } \\
\text { ties (FirstWorld Nigeria Limited). }\end{array}$ \\
\hline & & $\begin{array}{l}\text { The transfer of management and ownership in this firm } \\
\text { was facilitated by the incumbent CEO's capacity to trust } \\
\text { successors, willingness to give adequate compensation, his } \\
\text { competencies and skills, capabilities, willingness to teach, } \\
\text { ability to tolerate and discipline potential successor when } \\
\text { the need necessary, educational status, health condition, } \\
\text { his youthful age, his experience, and his gender blindness } \\
\text { (SirMighty Investment). }\end{array}$ \\
\hline \multirow{2}{*}{$\begin{array}{l}\text { Charac- } \\
\text { teristics } \\
\text { of the } \\
\text { potential } \\
\text { succes- } \\
\text { sor }\end{array}$} & \multirow{2}{*}{$\begin{array}{l}\text { Interest in the business, commit- } \\
\text { ment to the business, willingness } \\
\text { and capacity to be an apprentice, } \\
\text { willingness to take risk, willing- } \\
\text { ness to take responsibilities, } \\
\text { trustworthiness, integrity, level of } \\
\text { training received, age, competen- } \\
\text { cies and skills, capabilities, educa- } \\
\text { tional status, and level of experi- } \\
\text { ences garnered. }\end{array}$} & $\begin{array}{l}\text { This potential successor was selected because he showed } \\
\text { so much Interest and commitment to the business, willing- } \\
\text { ness and capacity to be an apprentice, and willingness to } \\
\text { take risk and responsibilities (Graceful Resources Nigeria). }\end{array}$ \\
\hline & & $\begin{array}{l}\text { Ugo was selected by the founder because of the qualities } \\
\text { he exhibited. These qualities include trustworthiness, integ- } \\
\text { rity, willingness and dedication to training, youthful age } \\
\text { strength, competencies and skills, capabilities, educational } \\
\text { status, and level of experiences garnered. These qualities } \\
\text { contributed to the success of the transfer process (Uduego } \\
\text { W.A. Limited). }\end{array}$ \\
\hline \multirow{2}{*}{$\begin{array}{l}\text { Charac- } \\
\text { teristics } \\
\text { of the } \\
\text { family } \\
\text { SME }\end{array}$} & \multirow{2}{*}{$\begin{array}{l}\text { These include: shared/agreed-on } \\
\text { vision among the incumbent, the } \\
\text { spouse, the children and top level } \\
\text { managers in the business; intra- } \\
\text { and inter-communication be- } \\
\text { tween the family and the busi- } \\
\text { ness; the nature of the relation- } \\
\text { ship existing among the family } \\
\text { members and between the family } \\
\text { and the business; the liquidity } \\
\text { level; size of the firm; organiza- } \\
\text { tional culture; and favourable } \\
\text { business environment. }\end{array}$} & $\begin{array}{l}\text { We had successful succession without conflicts because of } \\
\text { the shared/agreed-on vision among the incumbent, the } \\
\text { spouse, the children and top level managers in the firm. } \\
\text { The success was also enhanced by the intra-and inter- } \\
\text { communication between the family and the business (I \& I } \\
\text { Enterprises). }\end{array}$ \\
\hline & & $\begin{array}{l}\text { The transfer of the management and ownership of our firm } \\
\text { was enhanced by the nature of the relationship existing } \\
\text { among the family members and between the family and } \\
\text { the business. The money available, culture, size and envi- } \\
\text { ronment of the firm also contributed to the success of the } \\
\text { transfer (IK \& Bros Nigeria Limited). }\end{array}$ \\
\hline
\end{tabular}

Source: own study. 


\section{Factors that contribute to post-succession performance and their role in the post-succession performance}

The themes identified in this subsection as the contributory factors in post-succession performance are the culture of making succession planning an on-going or a continuous process, the characteristics of the incumbent and the characteristics of the family SME. The respondents reported that the culture of continuous or on-going succession planning process even after a management and/or ownership succession ensures that the children of the incumbent who are interested in the business are actively involved in the operations of the SMEs in the quest to be selected as potential successors. This process keeps the incumbent up and doing in a bid to expose the potential successors to every aspect of the SME through apprenticeship programmes and on-the-job trainings. The outcomes of these developmental programmes constitute the basis on which the potential successors are often recommended for trials in the daily routines or tasks of the SMEs. The respondents agreed that the characteristics of the incumbent that contribute to post-succession performance help the incumbent of the SME to positively influence the behaviour and work attitude of members of the SME towards improved financial/non-performance of the SME. The respondents are of the view that the characteristics of the family-owned SME that contribute to post-succession performance help to create organizational culture and work environment that enhances the knowledge and skills of employees, commitment to organizational goals, and financial/nonperformance of the SME. The factors, financial/non-financial performance and relevant quotes for post-succession performance are presented in Table 2.

Table 2. Summary of the contributory factors to post-succession performance

\begin{tabular}{|c|c|c|}
\hline Factor & $\begin{array}{c}\text { Post succession financial } \\
\text { and non-financial performance }\end{array}$ & Relevant quote \\
\hline \multirow{2}{*}{$\begin{array}{l}\text { The culture of mak- } \\
\text { ing succession plan- } \\
\text { ning an on-going or a } \\
\text { continuous process. }\end{array}$} & \multirow{2}{*}{$\begin{array}{l}\text { The aggregate effect of these } \\
\text { efforts on the sales, profits, em- } \\
\text { beddedness of the SMEs in the } \\
\text { family, sustainability of the } \\
\text { SMEs, acquired capital of the } \\
\text { SMEs and the reputation of the } \\
\text { families/SMEs is always posi- } \\
\text { tive. }\end{array}$} & $\begin{array}{l}\text { The culture of making succession planning an } \\
\text { on-going or a continuous process even after the } \\
\text { successor had taken over the management } \\
\text { and/or ownership of the firm drives every stake- } \\
\text { holder into a goal and result oriented hard work } \\
\text { (Alpha Outfits). }\end{array}$ \\
\hline & & $\begin{array}{l}\text { The culture of making succession planning an on- } \\
\text { going or a continuous process has helped us to } \\
\text { achieve increase in sales and profits, unity of the } \\
\text { SME and the family, level of control the family has } \\
\text { in the business, increase in the capital of the SME } \\
\text { and improvement in the reputation of the family } \\
\text { and the SME (SunyBest Nigeria Limited). }\end{array}$ \\
\hline $\begin{array}{l}\text { Characteristics of the } \\
\text { incumbent. The char- } \\
\text { acteristics of the in- } \\
\text { cumbent that con- } \\
\text { tribute to post-suc- } \\
\text { cession performance } \\
\text { are commitment to } \\
\text { the business, integ- } \\
\text { rity, level of training }\end{array}$ & $\begin{array}{l}\text { The character of the incumbent } \\
\text { facilitates the unrelated diversi- } \\
\text { fication of the SME. In addition, } \\
\text { the SMEs are witnessing in- } \\
\text { crease in sales, investments, } \\
\text { profits and staff strength, and } \\
\text { improvement in staff commit- } \\
\text { ment and the reputation of the } \\
\text { family and the SMEs. }\end{array}$ & $\begin{array}{l}\text { The incumbent/CEO of this supermarket has } \\
\text { been driven by commitment, training received, } \\
\text { experience and his young age to increase the } \\
\text { number of freedom supermarkets in the region. } \\
\text { Based on his integrity, level of education/train- } \\
\text { ing, good health condition, willingness to assign } \\
\text { responsibilities, delegate authority and take risk, } \\
\text { he started networking with other business own- } \\
\text { ers and firms. This is helping to improve and in- } \\
\text { crease his competencies, skills and capabilities, }\end{array}$ \\
\hline
\end{tabular}




\begin{tabular}{|c|c|c|}
\hline Factor & $\begin{array}{c}\text { Post succession financial } \\
\text { and non-financial performance }\end{array}$ & Relevant quote \\
\hline $\begin{array}{l}\text { received, age, willing- } \\
\text { ness to take risk, ed- } \\
\text { ucational status, } \\
\text { health condition, } \\
\text { willingness to dele- } \\
\text { gate authority, will- } \\
\text { ingness to assign re- } \\
\text { sponsibilities, willing- } \\
\text { ness to give ade- } \\
\text { quate compensation, } \\
\text { competencies and } \\
\text { skills, capabilities ac- } \\
\text { quired, gender blind- } \\
\text { ness, willingness to } \\
\text { network, and level of } \\
\text { experiences gar- } \\
\text { nered. }\end{array}$ & & $\begin{array}{l}\text { and enabling him to diversify into other lines of } \\
\text { businesses. In addition, today, the supermarkets } \\
\text { and the other businesses are witnessing increase } \\
\text { in sales, investments, profits and staff strength, } \\
\text { and improvement in staff commitment to the } \\
\text { businesses and the reputation of the family and } \\
\text { the SMEs (Freedom Supermarkets). }\end{array}$ \\
\hline $\begin{array}{l}\text { Characteristics of the } \\
\text { family SME. The } \\
\text { characteristics of the } \\
\text { SME that contribute } \\
\text { to post-succession } \\
\text { performance are } \\
\text { shared/agreed-on vi- } \\
\text { sion, relationship, } \\
\text { communication and } \\
\text { organizational cul- } \\
\text { ture. }\end{array}$ & $\begin{array}{l}\text { The characteristics of the SME } \\
\text { contribute to improvements in } \\
\text { investments, profit, family/busi- } \\
\text { ness reputation, survivability, } \\
\text { sustainability, embeddedness, } \\
\text { organizational culture and sat- } \\
\text { isfaction level of the stakehold- } \\
\text { ers. }\end{array}$ & $\begin{array}{l}\text { Ever since the incumbent took over the manage- } \\
\text { ment and ownership of this business, there have } \\
\text { been improvements in investments, profit, fam- } \\
\text { ily/business reputation, level of control the fam- } \\
\text { ily has in the business, the management of de- } \\
\text { mands on the business, unity of the firm and the } \\
\text { business, business culture and satisfaction level } \\
\text { of the stakeholders. This is because the incum- } \\
\text { bent has maintained the practice of conceiving a } \\
\text { vision, sharing it with the spouse, children and } \\
\text { top level managers and allowing them to make } \\
\text { their respective inputs into the vision before } \\
\text { adopting or adapting it. The incumbent has also } \\
\text { insisted that a positive relationship be created } \\
\text { and maintained among all the stakeholders and } \\
\text { that further issues arising from the agreed-on vi- } \\
\text { sion should be freely communicated. Further, } \\
\text { that the implementation of the agreed-on vision } \\
\text { be guided by the organizational culture. This } \\
\text { practice makes all those who agreed to the vi- } \\
\text { sion to be committed to ensuring that the result- } \\
\text { ant effect of its implementation on the financial } \\
\text { and non-financial performance of the business } \\
\text { as a whole is positive (J \& J Nigeria Limited). }\end{array}$ \\
\hline
\end{tabular}

Source: own study.

The findings of this study are somewhat consistent with previous results (Bocatto et al., 2010; Bouguerra et al., 2016; Chaimahawong \& Sakulsriprasert, 2012; De Alwis, 2016; Overbeke et al., 2015; Sharma \& Sumita, 2013; Utami, 2017; Wahjono et al., 2014). Despite the importance of and availability of a well written management and/or ownership succession plan, lack of it in a family-owned SME may not imply absence of succession plan as culturally orientated family-owned SMEs where mortality is not openly discussed maintain unwritten 
succession plan. This is because an on-going succession plans whether written or not contributes to successful management and ownership transfer and ensures that the performance of the firm is improved even after the transfer. Successful succession is a function of the incumbent's willingness to plan for succession, progressive delegation of authority, acceptance of clearly specified roles, the incumbent's willingness to step aside, continued family involvement, and the successor's willingness to succeed. Most importantly, the selected potential successor must imbibe and exhibit behaviour which the incumbent desires and appreciates (Amran \& Ahmad, 2010; Lansberg \& Gersick, 2015; Pyromalis \& Vozikis, 2009).

Old age make incumbents more conservative, less likely to take risk, more reliant on their own source of information for making decisions and increases in them the likelihood of disability or death. When the incumbents are older, the chances of success in succession are higher compared to when they are younger. In the past, family business incumbents were not highly educated. However, today, the number of successful family business successions increases as the number of educated incumbents increase. Family business incumbents need to be willing to trust and adequately reward potential successors as this will help them succeed in the succession process (Amran \& Ahmad, 2010; Pyromalis \& Vozikis, 2009).

Incumbents prefer the eldest son to other children, and men to women as successors when planning for succession in the family business. The proponents of the traditional perspectives of gender opined that gender is biologically determined. They characterized men as "instrumental" (i.e., "get things done") and women as "expressive" (i.e., caring, nurturing and domestic responsibilities related qualities) (Judge \& Livingston, 2008; Mueller \& Dato-On, 2008). The theory assumes that one must have either a masculine or a feminine sex-role orientation, because these role orientations are mutually exclusive and incompatible. The arguments that ensued concerning this perspective led to the emergence of the non-traditional perspective of gender as socially constructed rather than biologically determined sex roles (Mueller \& Dato-On, 2008). Gender role orientation is determined by individual attitudes, values and self-concepts. Consequently, expressiveness may manifest in males and instrumentality may be exhibited by females (Judge \& Livingston, 2008; Mueller \& Dato-On, 2008). Also, the more traditional a daughter's gender role orientation, the less likely she will become a successor. The more traditional a father's gender role orientation, the less likely he will appoint her as a successor (Judge \& Livingston, 2008). Today, attention is gradually shifting to the daughters and women as family business incumbents are increasingly becoming gender blind. Overbeke et al. (2015) opined that shared vision between a father and his daughter may help to transform the daughter into a successor. It may also help the daughter to surmount gender barriers, thereby making the daughter more efficient than the son.

The children of the incumbents who become actively involved in family business as apprentices at an early age are likely to be more adequately prepared to take over managerial and/or ownership responsibilities in the family business at a young age (Schroder, Schmitt-Rodermund \& Arnaud, 2011). This young age of the children influence the incumbent's choice during the succession process (Wiklund, Nordqvist, Hellerstedt \& Bird, 2013). For effective succession process in family business succession, the potential successor needs to be educated, experienced and skilled to ensure the success of the succession process (Amran \& Ahmad, 2010; Georgiou \& Vrontis, 2013). A formally educated potential successor who worked elsewhere before joining the family business will be more skilful, 
competent and committed. When such potential successor reads books and articles on family business, regularly attends business-related courses and seminars, and receives mentoring from someone other than the incumbent, he/she stands to make the succession process successful (De Massis, Chua \& Chrisman, 2008). A potential successor's commitment level and capability to take over the business is not fully tied to the incumbent. The potential successor can develop the needed traits with or without the effort of the incumbent. Another equally important characteristic of a potential successor is that he/she must be interested and willing to take over the family business (Sharma, Chrisman \& Chua, 2004; Venter, Boshoff \& Maas, 2005).

Integrity, risk taking, willingness to take responsibility and commitment to the business are the most desirable traits required to make succession successful (Chrisman, Chau \& Sharma, 1998; Sharma et al., 2001). The four different forms of commitment (i.e., affective, normative, calculative, and imperative) often develop simultaneously because of multiple motives (Sharma \& Irving, 2005). However, the two strongest forms of commitment required of successors are affective (characterized by the successor's genuine desire to be in the family firm) and normative (occurs when family members join the firm out of obligation) commitments (Sharma \& Irving, 2005). In spite of the different levels of binding strength which commitment create between a successor and the family business, trust between the successor and the family firm constitute a resource that contributes to successful succession (Anderson, Jack \& Dodd, 2005; Sharma \& Irving, 2005).

Embedded in the family system are social norms passed down from one generation to another irrespective of age, educational achievement, religion and marital status. Most of these societal norms are carried to the family business and subsequently made part of the business system. This culture affects the way such business is conducted (GTI, 2000). It affects the relative value placed on education, which, in turn, influences the development of a potential successor. Hence, successful succession as a cultural attitude is formed through the complex process of succession (OECD, 1998). Aside culture, one of the strongest factors that sustain every existing business beyond generations is harmonious relationship. This relationship could be at the level of family members, clients and customers, employer and employees, family members and customers, family members and employees, stakeholders and many others (Paul et al., 2017).

A strong relationship between the incumbent and the potential successor is one of the keys to successful transfer. This relationship allows the potential successor to gain understanding about the culture and intricacies of the firm. The quality of the relationship between the incumbent and the potential successor is a critical determinant of the success of the succession process in family business (Chrisman, Chua \& Sharma, 2008; Lansberg \& Gersick, 2015; Venter et al., 2005). The relationship between the family and the business ensures that the incumbent is directly involved in the training of the potential successor (Venter et al., 2005). The quality of the relationship between the incumbent and other family members, such as the siblings, is also considered to be important in the succession process (Chaimahawong \& Sakulsriprasert, 2012; Georgiou \& Vrontis, 2013) since the incumbent cannot operate effectively without the support of the family members (Venter et al., 2005).

Favourable changes in market conditions (Cespedes \& Galford, 2004; De Massis et al., 2008) and the business environment can affect the financial standing of the family firm positively. This by extension can make the management and/or ownership succession successful 
(Cespedes \& Galford, 2004; Venter et al., 2005). Furthermore, the larger the size of the business, the higher the chance that the potential successor will take over the business due to the attractive monetary rewards (Venter et al., 2005). The incumbent and potential successor must adjust their behaviours so that as they communicate in the form of utterances, written messages, gestures, facial expressions and other types of interactions, the inherent information flow which facilitates successful succession, will in addition help to enhance and sustain the post-succession performance of the family firm (Handler, 1994). During the process of management and/or ownership succession, the characteristics of the incumbent, potential successor and the family SMEs are very important in facilitating the success of the process. Chaimahawong and Sakulsriprasert (2012) confirmed that while family business characteristics and personal characteristics of the incumbents and the successors make the highest level of impact on the successful succession, the successful succession engenders positive post-succession performance of family businesses.

When the founder retires from active business activities or leaves the business on account of incapacitation, his/her selected potential successor takes over the management and/or ownership of the SME. In the event of sudden death, the South Eastern Nigeria succession law applies in the management and/or ownership succession of the SME. This law is based on gender and birth order. Thus, it follows the primogeniture system. Primogeniture is a system where the oldest son (Okpala) succeeds a founder/CEO or family descendant/CEO in the ownership and management of the family business.

\section{CONCLUSIONS}

This study has revealed that the studied family-owned SMEs have no written succession plan. Aside, the contributory factors to the successful management and/or ownership succession were identified as characteristics of succession planning, the incumbent, the potential successors and the family SMEs. Furthermore, the contributory factors to the post-succession financial and non-financial performance of the family-owned SMEs are the culture of making succession planning an on-going or a continuous process, the characteristics of the incumbent and the characteristics of family-owned SME. These factors help to make the children of the incumbent in the SME to be actively involved in the operations of the SMEs and the incumbents to be committed to their training. Through these factors, the behaviour, work attitude of employees and organizational culture of the SME is positively influenced. The aggregate effect is improvement in the financial and non-financial performance of the family-owned SMEs.

The theoretical contribution of this study to knowledge is in identifying the contributory factors to successful management and/or ownership succession of the family-owned SMEs as the characteristics of succession planning, the incumbent, the potential successors and the family SMEs. The study also identified the contributory factors to the post-succession financial and non-financial performance of the family-owned SMEs. That is, the culture of making succession planning an on-going or a continuous process, the characteristics of the incumbent and the characteristics of the family-owned SME. In addition, the role of the postsuccession factors in the post-succession financial and non-financial performance of familyowned SMEs. The implications of these findings are that incumbents of family-owned SMEs can achieve successful succession and post-succession financial and non-financial performance by inculcating the identified characteristics in their potential successors. Also, the 
identified characteristics can be made part of the culture of the SMEs. Researchers can as well use these factors and characteristics as proxies in studies on the successful succession and post-succession financial and non-financial performance of family-owned SMEs.

The limitation of this study is that its scope is limited to only three sectors and the South Eastern Nigeria, thus excluding respondents from other sectors like agriculture and other geographical zones like South Southern, South Western, North Eastern, North Western, and North Central Nigeria. The implication of this is that the generalization of the findings will be limited to these sectors and the zone. Further research could be conducted to include respondents from other sectors and zones using qualitative and/or quantitative methodology. Better still, this study could be replicated in other parts of the world to confirm the current findings.

\section{REFERENCES}

Aderonke, J. (2014). Culture determinant and family business succession in Jos metropolis, Plateau State, Nigeria. Journal of Emerging Trends in Economic and Management Sciences, 5(5), 379-390.

Akani, V.C. (2015). Management succession planning and corporate survival in Nigeria: A study of banks in Port Harcourt. European Journal of Business and Management, 7(27), 153-176.

Aldamiz-Echevarría, C., Idígoras, I. \& Vicente-Molina, M. (2017). Gender issues related to choosing the successor in the family business. European Journal of Family Business Research, 7, 54-64. doi: 10.1016/j.ejfb.2017.10.002

Amran, N.A. \& Ahmad, A.C. (2010). Family succession and firm performance among Malaysian companies. International Journal of Business and Social Science, 1(2), 193-203.

Amran, N.A. (2011). The effect of owner's gender and age to firm performance: A review on Malaysian public listed family businesses. Journal of Global Business and Economics, 2(1), 104-116.

Anderson, A.R., Jack, S.L. \& Dodd, S.D. (2005). The role of family members in entrepreneurial networks: Beyond the boundaries of the family firm. Family Business Review, 18(2), 135-154.

Astrachan, J.H. \& Zellweger, T. (2008). Performance of family firms: A literature review and guidance for future research. ZfKE - Zeitschrift für KMU und Entrepreneurship, 56(1/2), 1-22.

Bennedsen, M., Fan, J.P., Jian, M. \& Yeh, Y.H. (2015). The family business map: Framework, selective survey, and evidence from Chinese family firm succession. Journal of Corporate Finance, 33, 212-226.

Bisogno, M. \& Vaia, G. (2017). The role of management accounting in family business succession. African Journal of Business Management, 11(21), 619-629. doi: 10.5897/AJBM2017.8396

Bjuggren, P., Nordström, L. \& Palmberg, J. (2015). Efficiency of female leaders in family and nonfamily firms. Ratio Working Paper No. 259.

Bjursell, C. (2011). Cultural divergence in merging family businesses. Journal of Family Business Strategy, 2(2), 69-77.

Bocatto, E., Gispert, C. \& Rialp, J. (2010). Family-owned business succession: The influence of preperformance in the nomination of family and nonfamily members: Evidence from Spanish firms. Journal of Small Business Management, 48(4), 497-523.

Bouguerra, A., Yezza, H. \& Mzoughi, M.N. (2016). Post-successions performance of family firms: The role of social skills and demographic characteristics of the successor. Strategic Management Quarterly September, 4(3), 75-86. doi: 10.15640/smq.v4n3a5

Boyd, B., Botero, I.C. \& Fediuk, T.A. (2014). Incumbent decisions about succession transitions in family Firms: A conceptual model. International Journal Financial Studies, 2, 335-358. doi:10.3390/ijfs2040335 
Bozer, G., Levin, L., Santora, J. (2017). Succession in family business: Multisource perspective. Journal of Small Business and Enterprise Development, 24(4), 753- 774. https://doi.org/10.1108/JSBED10-2016-0163

Cabrera-Suárez, M.K. \& Martín-Santana, J.D. (2012). Successor's commitment and succession success: Dimensions and antecedents in the small Spanish family firm. The International Journal of Human Resource Management, 23(13), 2736-2762. doi:10.1080/09585192.2012.676458

Cespedes, F.V. \& Galford, R.M. (2004). Succession and failure. Harvard Business Review, 82(6), 31-35.

Chaimahawong, V. \& Sakulsriprasert, A. (2012). Family business succession and post succession performance: Evidence from Thai SMEs. International Journal of Business and Management, 8(2), 19-28. doi:10.5539/ijbm.v8n2p19

Cheokas, G.G. (2013). In their own words: How does the succession experience of second generation family business owners influence future approaches to succession? (Unpublished Ph.D thesis), Georgia State University, Atlanta.

Chiang, H. \& Yu, H.J. (2018). Succession and corporate performance: The appropriate successor in family firms. Investment Management and Financial Innovations, 15(1), 58-67.

Chrisman, J.J., Chau, J.H. \& Sharma, P. (1998). Important attributes of success in family businesses: An exploratory study. Family Business Review, 12(1), 19-34.

Chrisman, J., Chua, J. \& Sharma, A. (2008). Factors preventing intra-family succession. Family Business Review, 21(2), 183-199.

Colli, A. (2011). Contextualizing performance of family firms: The perspective of business theory. Family Business Review, 20(10), 1-15.

Davis, J.A. (2014). Managing the family business: Leadership roles. Harvard Business School Working Knowledge, Baker Library.

De Alwis, A.C. (2016). Incumbents influence on family business succession process. European Journal of Business and Management, 8(13), 96-105.

De Massis, A., Chua, J.H. \& Chrisman, J.J. (2008). Factors preventing intra-family succession. Family Business Review, 21(2), 183-199.

Dumbu, E. (2018). Challenges surrounding succession planning in family-owned businesses in Zimbabwe: Views of the founding entrepreneurs of the businesses at Chikarudzo Business Centre in Masvingo District. The International Journal of Business Management and Technology, 2(2), 38-45.

El-Chaarani, H. (2014). The success keys for family firms: Comparison between Lebanese and French systems. Lebanese Science Journal, 15(2), 133-150.

European Commission (2009). Final report of the expert group, overview of family business relevant issues: Research, network policy measures and existing studies. Retrieved from http://ec.europa.eu/enterprise/policies/sme/promoting-entrepreneurship/family-business/family_business_expert_group_report_en.pdf on December 9, 2018.

Fan, J.P., Wong, T.J. \& Zhang, T. (2012). Founder succession and accounting properties. Contemporary Accounting Research, 29(1), 283-311.

Fernández-Aráoz, C., Iqbal, S. \& Ritter, J. (2015). Why family firms in East Asia struggle with succession. Harvard Business Review. Retrieved from https://hbr.org/2015/03/ why-family-firms-ineast-asia-struggle-with-succession on December 9, 2018.

Georgiou, T. \& Vrontis, D. (2013). Wine sector development: A conceptual framework toward succession effectiveness in family wineries. Journal of Transnational Management, 18(4), 246-272.

Ghee, W.Y., Ibrahim, M.D. \& Abdul-Halim, H. (2015). Family business succession planning: Unleashing the key factors of business performance. Asian Academic of Management Journal, 20(2), 103-126. 
Giovannoni, E., Maraghini, M.P. \& Riccaboni, A. (2011). Transmitting knowledge across generations: The role of management accounting practice. Family Business Review, 24(2), 126-150.

Griffeth, R.W., Allen, D.G. \& Barrett, R. (2006). Integration of family-owned business succession with turnover and life cycle models: Development of a successor retention process model. Human Resource Management Review, 16(2), 490-507.

GTI (2000). PRIMA international research report. London: Grant Thornton International.

Hadryś-Nowak, A. (2018). When successor becomes the leader of international family business? A case study from Poland. Paper presented at the 9th ENTRE Conference/5th AIB-CEE Chapter Annual Conference, Kraków, Poland, September 12-14.

Handler, W. (1994). Succession in family business: A review of the research. Family Business Review, $7(I), 133-157$.

Hania, M.F. (2012). Factors influencing family business succession (case study: Gaza family businesses). Department of Business Administration, Faculty of Commerce, Islamic University, Gaza.

Hiebl, M.R. (2013). Risk aversion in family firms: What do we really know? The Journal of Risk Finance, 14(1), 49-70.

Iraki, W.N. (2009). The family as the forgotten foundation of long term growth in every economy. Business Daily, Nation Media Group, Nairobi.

Jamali, D. (2009). Constraints and opportunities facing women entrepreneurs in developing countries. Gender Management, 24(4), 232-251.

Judge, T.A. \& Livingston, B.A. (2008). Is the gap more than gender? A longitudinal analysis of gender, gender role orientation, and earnings. Journal of Applied Social Psychology, 93, 994-1012. doi: 10.1037/0021-9010.93.5.994

Kansikas, J. \& Kuhmonen, T. (2008). Family business succession: Evolutionary economics approach. Journal of Enterprising Culture, 16(03), 279-298.

Kiilu, J.M. \& Ntale, J.F. (2018). Businesses: An empirical investigation of Nairobi Central Business District of Kenya. European Journal of Business and Management, 10(20), 91-97.

Krishnan, R.V. (2012). SME and succession planning. Retrieved from http://search.proquest.com/ docview/1321759146? accountid=458http://linksource.ebsco.com/linking.aspx?sid=ProQ\%3

Anewsstand\&fmt=journal\&genre=unknown\&issn=\&volume=\&issue $=\&$ date $=20120511 \&$ spage $=\&$ title $=$ Businessline \&atitle $=S M E+$ and + succession+planning \&au $=$ Krishnan $\% 2 C+R+V e n-$ kata\&isbn=\&jtitle=Businessline\&btitle=\&id=doi on December 9, 2018.

Lansberg, I. \& Gersick, K. (2015). Educating family business owners: The fundamental intervention. Academy of Management Learning \& Education, 14(3), 400-413. doi.:10.5465/amle.2014.0254.

Maalu, J., McCormick, D., K'Obonyo, P. \& Machuki, V. (2013). Succession strategy and performance of small and medium family businesses in Nairobi, Kenya. International Journal of Education and Research, 1(6), 1-22.

Maciel, A.S., Ramos, M.I.G., Aguilar, J.L.E. \& Reyna, J.M.M. (2015). The influence of family relationship in the succession: A factorial analysis of Mexican enterprises. Journal of Family Business Management, 5(2), 238-256.

Mejbri, K.M. \& Affes, H. (2012). Determinants of intention and succession planning in Tunisian family business. International Journal of Business and Social Science, 3(12), 118.

Michel, A. \& Kammerlander, N. (2015). Trusted advisors in a family business's succession- planning process - An agency perspective. Journal of Family Business Strategy, 6(1), 45-57.

Miller, S.P. (2015). Developing next-generation leadership talent in family business: The family effect (Unpublished Ph.D thesis), Weatherhead School of Management. Retrieved from 
https://etd.ohiolink.edu/!etd.send_file?accession=case1427837349\& disposition=inline on December 9, 2018.

Molly, V., Laveren, E. \& Deloof, M. (2010). Family business succession and its impact on financial structure and performance. Family Business Review, 23(2), 131-147. doi: 10.1177/0894486510365062

Monday, J.U., Akinola, G.O., Olegbenla, P. \& Aladeraji, O.K. (2014). Strategic management and firm performance: A study of selected manufacturing companies in Nigeria. European Journal of Business and Management, 7(2), 161-171.

Mueller, S.L. \& Dato-On, M.C. (2008). Gender-role orientation as a determinant of entrepreneurial self-efficacy. Journal of Development Entrepreneurship, 13, 3-20. doi: $10.1142 / \mathrm{S} 108494670800082 \mathrm{X}$

Musa, B.M. \& Semasinghe, D.M. (2014). Leadership succession problem: An examination of small family businesses. European Journal of Business and Management, 6(34), 301-306.

Nordqvist, M., Wennberg, K. \& Hellerstedt, K. (2013). An entrepreneurial process perspective on succession in family firms. Small Business Economics, 40(4), 1087-1122.

Obadan, J.A. \& Ohiorenoya, J.O. (2013). Succession planning in small business entreprises in Edo State. European Scientific Journal, 9(31), 64-76.

Oduwusi, O.O. (2018). Succession planning as a key to effective managerial transition process in corporate organizations. American Journal of Management Science and Engineering, 3(1), 1-6. doi: 10.11648/j.ajmse.20180301.11

OECD (1998). Fostering entrepreneurship. Paris: Organization for Economic Co-operation and Development (OECD).

Ogbechie, R. \& Anetor, F.O. (2015). An appraisal of succession planning in family-owned businesses in Lagos State, Nigeria. European Journal of Business and Management, 7(12), 1-5.

Ogundele, O.J.K., Idris, A.A. \& Ahmed-Ogundipe, K.A. (2012). Entrepreneurial succession problems in Nigeria's family businesses: A threat to sustainability. European Scientific Journal, 8(7), 208-227.

Okafor, L.I., Onifade, T.A. \& Ogbechi, A.D. (2018). Analytical review of small and medium scale enterprises in Nigeria. International Journal of Small Business and Entrepreneurship Research, 6(2), 32-46.

Onuoha, B.C. (2013a). Wealth creation, retirement and succession planning of entrepreneurs in South-East, Nigeria. International Business and Management, 7(1), 99-105.

Onuoha, B.C. (2013b). Poor succession planning by entrepreneurs: The bane of generational enterprises in South-East, Nigeria. AFRREV International Journal of Arts and Humanities, 2(2), 270-281.

Overbeke, K.K., Bilimoria, D. \& Somers, T. (2015). Shared vision between fathers and daughters in family businesses: The determining factor that transforms daughters into successors. Frontiers in Psychology, 6(625), 1-15. doi: 10.3389/fpsyg.2015.00625

Paul, V., Barde, B.E., Abbah, J.E.I. \& Idika, K. (2017). Effects of intra-family relationship on post-succession performance of selected family businesses in North East Nigeria. International Journal of Development Strategies in Humanities, Management and Social Sciences, 7(3), 134-149.

Phikiso, Z. \& Tengeh, R.K. (2017). Challenges to intra-family succession in South African townships. Academy of Entrepreneurship Journal, 23(2), 1-13.

Poza, E.J. (2013). Family Business. Mason, OH: South-Western Cengage Learning.

Prencipe, A., Bar-Yosef, S. \& Dekker, H.C. (2014). Accounting research in family firms: Theoretical and empirical challenges. European Accounting Review, 23(3), 361-385.

Pyromalis, V.D. \& Vozikis, G.S. (2009). Mapping the successful succession process in family firms: Evidence from Greece. International Entrepreneurship and Management Journal, 5(1), 439-460. 
Rotich, E. (2014). The effects of succession planning on financial performance of family owned supermarkets in Nairobi County. University of Nairobi Repository.

Saan, R., Enu-Kwesi, F. \& Nyewie, F.R. (2018). Factors influencing succession planning for continuity of family-owned businesses in the Wa Municipality, Ghana. Universal Journal of Management, 6(5), 165-177. doi: 10.13189/ujm.2018.060504.

Salvato, C. \& Moores, K. (2010). Research on accounting in family firms: Past accomplishments and future challenges. Family Business Review, 23(3), 193-215.

Schroder, E., Schmitt-Rodermund, E. \& Arnaud, N. (2011). Career choice intentions of adolescents with family business background. Family Business Review, 24(4), 305-321.

Sharma, P. \& Chrisman, J.J. \& Chua, J.H. (1997). Strategic management of the family business: Past research and future challenges. Family Business Review, 10(1), 1-35.

Sharma, P., Chrisman, J.J. \& Chua, J.H. (2003). Succession planning as planned behaviour: Some empirical results. Family Business Review, 16(1), 1-15.

Sharma, P., Chrisman, J. \& Chua, J. (2004). An overview of the field of family business studies: current status and directions for the future. Family Business Review, 17(1), 1-36.

Sharma, P., Chrisman, J.J., Pablo, A.L. \& Chua, J.H. (2001). Determinants of initial satisfaction with the succession process in family firms: A conceptual model, Entrepreneurship Theory and Practice, 25(3), 17-35.

Sharma, P. \& Irving, P.G. (2005). Four bases of family business successor commitment: Antecedents and consequences. Entrepreneurship: Theory and Practice, 29(1), 13-33.

Sharma, A. \& Sumita, D. (2013). Small scale family business succession and sustainability: A study in Chattisgarh. SDMIMD Journal of Management, 4(2), 17-27.

Stalk, G. \& Foley, H. (2012). Avoid the traps that can destroy family businesses. Harvard Business Review, 90(1), 25-227.

Surdej, A. \& Wach, K. (2012). The dynamics of succession in family businesses in Poland - Empirical results. Economia Marche Journal of Applied Economics, XXXI(2), 109-128.

The European Commission (2008). Overview of family business relevant issues. A study conducted by the Austrian Institute for SME Research.

Utami, C.W. (2017). The role of personality system succession pattern in family business in Indonesia. Scholars Journal of Economics, Business and Management, 4(12), 870-879. doi: 10.21276/sjebm.2017.4.12.1

Venter, E., Boshoff, C. \& Maas, G. (2005). The influence of successor-related factors on the succession process in small and medium-sized family businesses. Family Business Review, 18(4), 283303. doi: 10.1111/j.1741-6248.2005.00049.

Wahjono, S.I., Wahjoedi, W., Idrus, S. \& Nirbito, J.G. (2014). Succession planning as an economic education to improve family business performance in East Java Province of Indonesia. Journal of Asian Scientific Research, 4(11), 649-663.

Walsh, G. (2011). Family business succession: Managing the all-important family component. Retrieved from http://www.kpmg.com/ca/en/services/kpmg-enterprise /centre- for-family-business/documents/3468_succession.pdf. on December 9, 2018.

Wang, C. (2010). Daughter exclusion in family business succession: A review of the literature. Journal of Family \& Economic, 31(4), 475-484.

Warnar, P. (2012). Family business and knowledge transfer: How to survive to the next generation. Delft University of Technology. 
Wiklund, J., Nordqvist, M., Hellerstedt, K. \& Bird, M. (2013). Internal versus external ownership transition in family firms: An embeddedness perspective. Entrepreneurship Theory and Practice, 37(6), 1319-1340.

Williams, D.W., Zorn, M.L., Russell Crook, T. \& Combs, J.G. (2013). Passing the torch: Factors influencing transgenerational intent in family firms. Family Relations, 62(3), 415-428.

Ye, J., Parris, M.A. \& Waddell, D. (2013). The succession decision in Chinese-Australian family businesses: An exploratory study. Small Enterprise Research, 20(2), 110-125. doi:10.5172/ser.2013.20.2.110

Zahrani, M.A., Nikmaram, S. \& Latifi, M. (2014). Impact of family business characteristics on succession planning: A case study in Tehran industrial towns. Iranian Journal of Management Studies, $7(2), 243-257$.

\section{Appendix: Interview guide}

1. How conversant are you with the succession process and post-succession performance of your organization?

2. What type of succession has taken place in your organization?

i. If family management succession, why was management not transferred together with ownership?

ii. If management and ownership, why were they transferred together?

3. How would you describe management/ownership succession planning in your organization?

4. Would you say management/ownership succession planning in your organization is in stages? If yes, can you describe the stages?

5. Do you agree that the succession planning enhanced the successful succession of the management/ownership of your organization? What are the characteristics?

6. What are your views on the characteristics of the incumbent that helped to make the management/ownership succession of your organization successful?

7. Can you identify the characteristics of the potential successor that helped to make the succession process of the management/ownership of your organization successful?

8. What in your opinion are the characteristics of your organization that facilitated the management and/or ownership transfer?

9. What aspect of the management/ownership succession planning contributed to the post-succession financial/non-financial performance of your organization? And how?

10. Do you think any of the characteristics of the incumbent is further enhancing the post-succession financial/non-financial performance of your organization? If yes, could you explain?

11. Which of the characteristics of your organization contributes to the post-succession financial/non-financial performance of the organization? And how?

12. Generally, do you agree that the successful management/ownership succession of your organization has improved the post-succession financial/non-financial performance of the organization? 


\section{Author}

\section{Kenneth Chukwujioke Agbim}

Kenneth Chukwujioke Agbim is a doctoral candidate in the Department of Management, University of Nigeria, Enugu, Nigeria. He has M.Sc. in Development Studies, MBA in Management and M.Sc. in Management. His research interests are in the areas of strategic entrepreneurship, family business development and business ethics.

Correspondence to: kennethagbim2012@gmail.com

ORCID (1) http://orcid.org/0000-0002-9204-3387

\section{Copyright and License}

(1) $\odot \Theta$

This article is published under the terms of the Creative Commons

Attribution - NoDerivs (CC BY-ND 4.0) License

http://creativecommons.org/licenses/by-nd/4.0/

Published by the Centre for Strategic and International Entrepreneurship - Krakow, Poland

The journal is co-financed in the years $2019-2020$ by the Ministry of Science contract no. 238/WCN/2019/1 concluded on 15 August 2019. 
